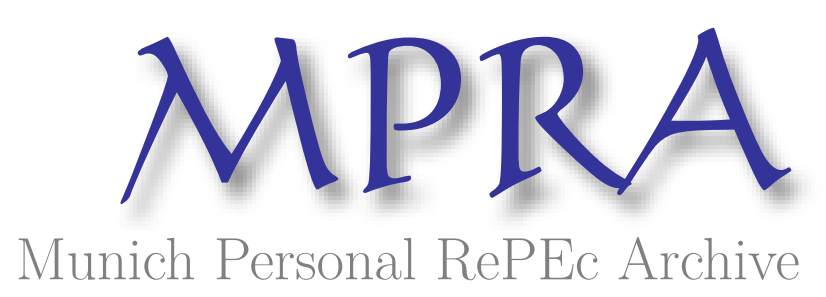

\title{
Impact of Land Certification on Land Rental Market Participation in Tigray Region, Northern Ethiopia
}

Holden, Stein T. and Deininger, Klaus and Ghebru, Hosaena

Norwegian University of Life Sciences

10 October 2007

Online at https://mpra.ub.uni-muenchen.de/5211/

MPRA Paper No. 5211, posted 08 Oct 2007 UTC 


\title{
Impact of Land Certification on Land Rental Market Participation in Tigray Region, Northern Ethiopia ${ }^{1}$
}

\author{
By \\ Stein Holden ${ }^{1}$, Klaus Deininger ${ }^{2}$ and Hosa'ena Ghebru ${ }^{1}$ \\ ${ }^{1}$ Department of Economics and Resource Management \\ Norwegian University of Life Sciences \\ P.O. Box 5033 \\ $1432 \AA$ As, Norway \\ Email: stein.holden@umb.no \\ 2 The World Bank \\ Washington D. C. \\ USA
}

\begin{abstract}
There is a renewed interest in whether land reforms can contribute to market development in Africa and whether land reforms can be pro-poor. This paper uses unique household panel data from Tigray region in Ethiopia to assess the impact of the 1998 low-cost land registration and certification reform on land rental market participation over a period of eight years after the reform, using random effects probit and tobit panel data models for land leased out and leased in, while correcting for unobservable heterogeneity and endogeneity of having certificate. The analysis revealed that the land reform contributed to increased land rental market participation. Female-headed households became more willing to rent out land and making land available for more efficient producers. Average areas leased out and leased in increased after certification. The land rental market remained characterised with significant and non-convex transaction costs also after the reform as evidenced by significant state dependence, a low response to own holding size and a high share of nonparticipation in the land market, leaving room for further improvement.
\end{abstract}

\section{Introduction}

New Land Reforms are again high on the global development agenda as illustrated by the recent establishment of a (High Level) Commission on Legal Empowerment of the Poor. Another evidence is the large expansion in the number of land reform projects funded by the World Bank; from 3 projects in FY 1990-94 to 19 (US\$0.7 billion) and 25 (US\$1 billion) in the 1995-99 and 2000-2004 periods (WB, 2006). Yet the empirical evidence on impacts of land reforms is mixed and there exist very few rigorous studies assessing their impacts.

We are aware of only two studies that have attempted to use the recently developed high quality impact assessment methods ${ }^{2}$ to assess such impacts of land reforms. One is a study in

\footnotetext{
${ }^{1}$ We are grateful for funding for data collection from Research Council of Norway, Norwegian Ministry of Foreign Affairs, NORAD and Norwegian Trust Fund and the data collection efforts of Fitsum Hagos and two groups of MSc-students from Norwegian University of Life Sciences. We also acknowledge logistical support from Mekelle University. We are thankful to Tewodros Kebede for assistance in calculations of the average partial effects of tobit models.
} 
Peru (Field and Torero, 2003) but the methodology in this study is also questioned (Mitchell, 2005). The other is a study in Mexico (Finan et al., 2005) who found that access to even a small plot of land can raise the household welfare substantially. Such methods have their limitations, however, when it comes to measuring economy-wide effects. In this paper we aim to assess the impacts of a broad land reform in form of a land registration and certification program that covered more than $80 \%$ of the rural farm households in Tigray, Ethiopia, within a period of about one year in 1998-99. We want to assess the impacts on the functioning of the land rental market in a country where all land is owned by the state but where individual households are given user rights, and rights to rent, inherit and bequeth the land. Such impacts are not likely to be there only for those who received certificates but also for others because of the economy-wide nature of the program and that we look at an economy-wide effect. Households without certificates after the reform may therefore not represent the adequate counterfactual in our analysis even if such households were randomly assigned as nonrecipients of certificates.

We are advantaged to have a unique panel data set covering 400 households in 16 communities in Tigray, where the first round survey was carried out one year (1997-98) before the land registration and certification took place, with three follow-up survey rounds about two, five and eight years after the land reform.

We apply random effects probit and tobit panel data models controlling for unobserved heterogeneity, state dependence and other exogenous variables to assess the impacts of the exogenously introduced reform program. Our analysis reveals a highly significant and positive effect of the land reform on land rental market participation and degree of participation on the tenant side of the market. On the landlord side of the market femaleheaded households with land certificates increased the land they rented out after the reform while the area they rented out decreased significantly over time after the reform for the same female-headed households.

The rest of the paper is organised as follows. We give an overview of the Ethiopian land policy changes over time in part two, followed by a theoretical model in part three. We

\footnotetext{
${ }^{2}$ See e.g. M. Ravallion (in press), 'Evaluating Anti-Poverty Programs.' in R.E. Evenson and Schultz, T. P., eds., Handbook of Agricultural Economics Volume 4, Amsterdam: North-Holland.
} 
present the methodology and data in part four and the results in part five, followed by our conclusions.

\section{The Ethiopian land policy: A brief historical overview and recent reforms}

Civil war and border conflicts have had a severe negative impact on the development of Ethiopia and land disputes and land policies have played a central role in these disputes. A military regime (Derg) took power from Haile Sellassie in 1974 and made all land state property. The regime followed up with frequent land redistributions and land allocation based on family size was practiced to maintain an egalitarian land distribution (Holden and Yohannes 2002, Rahmato 1984). After a long civil war in northern Ethiopia, the military government was overthrown and a new government formed in 1991. Eritrea was separated out and a more market-friendly policy introduced. Some authority was devolved from the federal to the regional governments. This was also the case for land policies where a new federal land proclamation was introduced in 1995 and followed up by regional land proclamations at different points in time after that allowing for some variation in the land laws across regions as long as these did not violate the federal land law.

The Tigray Region started a land certification process in 1998-99 and used simple traditional methods in the implementation. More than $80 \%$ of the population in the region had received land certificates when the process was interrupted by the war with Eritrea. This was at the time a unique large-scale low-cost approach that may set a new standard for land reforms which involves much lower costs than the traditional piecemeal high-tech approach that has dominated in most countries until recently (Deininger et al., 2007). The approach gives hopes that also the poor may benefit from land reforms while they most often have been excluded in countries where the high-cost high-tech methods have been used. This is therefore an excellent opportunity to study some of the benefits and weaknesses of this low-cost approach.

Other regions in Ethiopia have already learnt from the Tigray experience and have started to implement similar land registration and certification programs (ibid.). The Amhara Region started land registration and certification in 2003 with some donor support and used and tested more modern equipment. The Oromia and Southern Regions started very recently (2004) and the process is not yet completed in the latter three regions. The variation in the methods of the 
reforms across regions and communities gives excellent opportunities for research that can give useful insights about costs and benefits of alternative low-cost reform designs. The lessons from Ethiopia may also be highly relevant in some other poor countries characterised by high land pressure, tenure insecurity, severe rural poverty and land degradation (Deininger, et al., 2007).

Even though the land reforms in Ethiopia have contributed to an egalitarian land distribution, land rental markets are very active and are dominated by sharecropping arrangements (Teklu and Lemi, 2004; Holden and Ghebru, 2005; Bezabih and Holden, 2006; Pender and Fafchamps, 2006; Tadesse et al., Forthcoming).

Important policy concerns are whether the land reform in form of registration and certification has contributed to increased tenure security, espescially for the poor, including women. Anecdotal evidence from Tigray (MUT, 2003; Haile et al., 2005), that women think differently about their land certificates than men do as their tenure rights have been less secure than that of men, and the certificates may therefore have a higher value to them than they have to men. Men on the other hand may be more concerned about defending their plot borders and the certificates have little added value for that purpose since they do not contain any map of the plots. Furthermore, the cultural rule against women cultivating their land cause single women to depend on assistance from men or renting out or sharecropping out their land. This cultural taboo causes female-headed households in Tigray to be landlords and among the poorest of the poor (MUT 2003). Having a certificate may thus have strengthened the bargaining power of these female-headed households in the land rental market and this may have a poverty-reduction effect.

Another hypothesis forwarded by MUT (2003) was that certificates may be more important for old owners who may have received their land long time ago and therefore may have fewer witnesses to back up their land rights. In general, landowners will also tend to be older in villages where it is a long time since the last land redistribution. Old owners may also be less able to efficiently cultivate the land themselves. A land certificate may make them more willing to rent out their land because they feel more tenure secure.

Ghebru and Holden (Ghebru and Holden, Forthcoming) and Holden and Ghebru (2005) found considerable variation in the extent of market participation in land rental market across 
communities using a data Tigray from 2003 (part of the data used in this study). The land rental market therefore appeared to be characterised by substantial transaction costs and asymmetries due to rationing on the tenant side. Many tenants and potential tenants failed to rent in as much land as they wanted to (Ghebru and Holden, Forthcoming). A large share of the contracts was among kin and kinship ties appeared to improve access to land in the market (Holden and Ghebru, 2005). Another study in the Amhara region of Ethiopia (Deininger et al., Forthcoming) also found signs of high transaction costs in the land rental market. Similarly, Tikabo, Holden and Bergland found significant transaction costs in the land rental market in Eritrea (Tikabo et al., 2007).

MUT(2003) suggested that land certificates may not be important for land rental contracts and found no sign of changes in the land rental markets due to certificates. Their qualitative evidence from tenants indicated that tenants did not care whether the landowner has a certificate or not. What was more important was that they could trust the other party. With trust the certificate is unimportant. They also made the point that high enforcement costs may reduce the value of the certificate as an instrument to enforce contracts through the social court. Our data allow us to make quantitative assessments of whether certificates enhance the land rental market. Trust and enforcement possibilities are clearly important determinants of the transaction costs and have implications for the extent to which land certification can enhance the allocative efficiency of the land rental market.

\section{Theoretical model}

Early studies of transaction costs and adjustment in the land rental market include Bliss and Stern (Bliss and Stern, 1982), Bell and Susangkarn (Bell and Sussangkarn, 1988) and Skoufias (Skoufias, 1995). We develop theoretical models of landlord and tenant behaviour in the land rental market taking tenure insecurity and transaction costs into account. We build on Fafchamps (Fafchamps, 2004) and Holden and Ghebru (2005). Transaction costs in the land rental market are a function of tenure security that again depends on trust and the current and past land policies. This implies that transaction costs may be nonconvex in emerging markets where trust-based trade relationships among partners tend to develop gradually(Fafchamps, 2004). Past trade experience as landlord or tenant may therefore matter for current market access and degree of participation (Holden and Ghebru, 2005). This could be due to trust as well as reputation effects. This also implies that we should expect to find state dependency when analysing panel data from such market participation. 


\section{Landlord model}

We start by outlining the landlord model in a land rental market dominated by sharecropping. For simplicity we assume that the household maximises expected income $(y)$ from production on own land, rental income from rented out land $(R)$ and off-farm activity. The landlord household has a fixed endowment of land $\left(\bar{A}^{L}\right)$ and non-land resources $\left(\bar{N}^{L}\right)$. The non-land resources may be used in farm production or to generate off-farm income $\left(w N^{w}\right)$. The landlord gets a share $(1-\alpha)$ of the output $(q)$. Production risk may be one of the important reasons for sharecropping but we ignore this type of risk for the moment and focus only on the risk related to tenure insecurity. Furthermore, we assume that land and non-land resources are complements in agricultural production. We use the standard assumptions for the production functions; $q_{A}, q_{R}, q_{N}>0, q_{A A}, q_{R R}, q_{N N}<0, q_{A N}, q_{R N}, q_{N A}, q_{N R}>0$. The transaction costs in the land rental market are captured by a transaction cost function which implicitely captures trust and tenure insecurity which are a function of past and current land policies, earlier trade experience, landlord characteristics, and community characteristics. The transaction cost function, $c($.$) , is assumed to be non-decreasing in area rented out \left(R_{t}\right)$ and decreasing with earlier trade experience $\left(R_{t-n}\right)$. Tenure insecurity may increase or decrease with past and current land policies such as land redistribution, restictions on land renting, and land registration and certification interventions. Knowledge of new land policies may be imperfect and old policies may have an impact long after they have been officially stopped. Such policies may therefore affect the perceived tenure security and consequent expected costs and benefits of land renting. The expected income maximisation problem of the landlord is represented in equation (1) below where subscript $t$ represents current time period, superscript $L$ represents landlord, supercript $T$ represents tenant, superscript $V$ represents village, and superscript $W$ represents off-farm income-generating activity ${ }^{3}$. Tenure security is a consequence of past policies and is represented by $\xi\left(\int_{-\tau}^{t} \psi^{P} d t\right)$, where $c_{\xi}<0$,

$$
\begin{aligned}
& c_{R t} \geq 0, c_{R t-n} \leq 0 . \\
& \operatorname{Max}_{R} y_{t}^{L}=\left\{\begin{array}{l}
p q\left(\bar{A}_{t}^{L}-R_{t}, \bar{N}_{t}^{L}-N_{t}^{W} ; z^{L}\right)+p(1-\alpha) q\left(R_{t}, \bar{N}_{t}^{T}\right) \\
-c\left(\xi\left(\int_{-\tau}^{t} \psi^{P} d t\right), R_{t}, R_{t-n} ; z^{L}, z^{V}\right)+w N_{t}^{W}
\end{array}\right\}
\end{aligned}
$$

The first order condition for area rented out becomes;

\footnotetext{
${ }^{3}$ We suppress subscripts denoting households to keep notation simple.
} 
$\frac{\partial y}{\partial R_{t}}=\left\{\begin{array}{l}p(1-\alpha) q_{R}\left(R, \bar{N}_{t}^{T}\right)-p q_{A}\left(\bar{A}_{t}^{L}-R_{t}, \bar{N}_{t}^{L}-N_{t}^{W} ; z^{L}\right) \\ -c_{R}\left(\xi\left(\int_{-\tau}^{t} \psi^{P} d t\right), R_{t}, R_{t-n} ; z^{L}, z^{V}\right)\end{array}\right\} \leq 0 \perp R_{t} \geq 0$

Using the implicit function theorem it is trivial to show that area rented out will decrease with increasing transaction cost. Tenure insecurity due to land policies, like frequent land redistributions or restrictions on land renting, or lack of trust in tenants, are therefore likely to reduce willingness to rent out land. On the other hand, previous trade experience with tenants and policies that enhance tenure security, like land registration and certification is meant to do, should stimulate land rental activity, How quickly this effect appears depends on the speed of the dissemination of information and the trust in the government. These effects are also conditioned by observable and unobservable landlord $\left(z^{L}\right)$ and village $\left(z^{V}\right)$ characteristics.

However trivial this is theoretically it is of high policy relevance related to the new land policy reforms that sweep over many countries in Africa and other parts of the world. We are not aware of any other studies that have been able to utilise household panel data in this way to test the dynamic effects of a land reform on land rental market activity.

\section{Tenant model}

Based on the landlord model and empirical studies(Ghebru and Holden, Forthcoming) it is possible that tenants are rationed in the land rental market. This may be due to the sharecropping system that causes the land rental market not to have a price that clears the market. Likewise tenure insecurity and imperfect information about tenants may cause landlords to be cautious in their land renting-out decisions. Trust, reputation and earlier experience with tenants may therefore be important for their access. Likewise, alternative policies and policy reforms may affect tenants' degree of access to land in the land rental market. This means that we do not assume that tenants in general are able to rent in an optimal amount given their own resource situation. Based on Holden and Ghebru (2005) we assume that the tenants' access to land in the rental market may be formulated as follows; $\bar{R}_{t}^{T}=\sum_{L} \bar{R}_{t}^{T L}\left(c_{t}^{T L}\right)=\sum_{L} \bar{R}_{t}^{T L}\left\{{ }_{c}^{T L}+c_{t}^{T L}\left(\bar{A}_{t}^{T}, \bar{N}_{t}^{T}, \int_{-\Upsilon}^{t} \bar{R}_{t-n}^{T L} d t, \sum_{\mathrm{P}} \int_{-\Gamma}^{t} \psi_{t}^{P} d t ; z_{t}^{T}, z^{V}\right)\right\}$

This equation says that a tenant's access to land is a function of the transaction costs $(c)$ that consist of a minimum irreducable component $(\bar{c})$ and a part that depends on the land and non- 
land resources of the tenant, earlier participation in the land rental market $\left(\int_{-\mathrm{r}}^{t} \bar{R}_{t-n}^{T L} d t\right)$, and past and present land policy mixes $\left(\sum_{\mathrm{P}} \int_{-\Gamma}^{t} \psi_{t}^{P} d t\right)$ which may pull in different directions and have lagged effects. The access is also conditional on other observable and unobservable tenant characteristics (e.g. sex of household head) and village characteristics.

The models highlight that policy effects tend to be dynamic and may depend on past and initial conditions. They allow us to test the following hypotheses:

H1. Land rental market participation has increased after the land registration and certification (because land certificates have increased the feeling of tenure security among landlords, making them more willing to rent out their land).

$\mathrm{H} 2$. There is state dependence in the land rental market such that lagged market participation has a positive effect on later market participation. This may be due to the non-convex nature of the transaction costs (Fafchamps 2004).

H3. Female landlords that received certificates are likely to rent out more land after the reform (due to increased tenure security).

H4. Older landowners depend more on the certificates as a proof of their ownership, causing old landowners with certificates to be more willing to rent out their land (due to higher tenure security) (MUT 2003).

H5. Access to land in the land rental market has improved for tenants after the reform (follows if landlords have become more willing to rent out).

H6a. The effect of the reform is gradual and the full effect only comes after many years (lack of trust and information about potential partners cause cautious and gradual involvement in the market) (Fafchamps 2004) vs.

H6b. There is a non-linear effect of the reform on land rental market participation with strong initial effect (diminishing effect over time).

H7. Households that initially participated more in the land rental market and received certificates responded less than others that received certificates (because they already were more likely to have trusted partners and therefore face lower transaction costs).

H8. Land rental market activity increased most in communities with low share of participating households in the land rental market before the land reform H9. Having a land certificate had a more positive effect on land market participation in villages with low initial land rental market activity. 
H10. Land rental market participation increased more over time in villages with low initial paticipation in the land rental market (due to higher transaction cost-reducing potential of the reforms in villages where activity was initially low).

We will come back to how we wanted to test these hypotheses in part 4.2. below.

\section{Methodology}

\subsection{Econometric approach}

We used dynamic panel data models with binary and censored response variables and included controls for unobserved heterogeneity. We used probit form for the binary land rental market participation models and incorporated a lagged dependent variable along with strictly exogenous variables with standard random effects (Wooldridge 2005).

The dynamic probit model may be specified as follows;

$$
P\left(y_{i t}=1 \mid y_{i, t-1}, \ldots, y_{i 0}, z_{i}, c_{i}\right)=\Phi\left(z_{i t} \gamma+\rho y_{i, t-1}+c_{i}\right)
$$

where $y$ is the dependent variable conditioned on the lagged dependent variables, exogenous variables $\left(z_{i}\right)$ and unobserved household heterogeneity $\left(c_{i}\right)$. The unobserved heterogeneity is assumed to be additive inside the standard normal distribution function ( $\Phi)$ (ibid.).

The model allows us to test for state dependence. Previous participation in the land rental market may matter for current participation and the intial condition before the land reform may also affect the response.

The unobserved heterogenous effect may be written as (Wooldridge 2005) $c_{i}=\alpha_{0}+\alpha_{1} y_{i 0}+z_{i} \alpha_{2}+\alpha_{i}$

In this way the unobserved effect is modeled on the initial condition and exogenous variables to get a likelihood function that does not depend on the unobserved individual effects. This allows use of a likelihood function that has the same structure as the standard random effects probit model except that the explanatory variables at time period $t$ are $x_{i t}=\left\{1, z_{i t}, y_{i, t-1}, y_{i 0}, z_{i}\right\}$

It is possible to include interactions between $y_{i 0}$ and $z_{i}$ provided the model is linear in parameters.

The dynamic Tobit model with unobserved effects is specified as follows (Wooldridge, 2005); 
$y_{i t}=\max \left[0, z_{i t} \gamma+g\left(y_{i, t-1}\right) \rho+c_{i}+u_{i t}\right]$

$u_{i t} \mid y_{i, t-1}, \ldots, y_{i 0}, z_{i}, c_{i} \sim \operatorname{Normal}\left(0, \sigma_{\mathrm{u}}^{2}\right)$

for $t=1,2, . ., T$ time periods and $i=1,2, \ldots, N$ households in the cross-section. The $g($.$) function is$ formulated to allow the effect of lagged $y$ to be different depending on whether it was a corner solution or not. Wooldridge (ibid.) has shown how to obtain root- $N$-consistent estimates of the parameters. The model may be used to obtain average partial effects.

The dynamic corner solution model with unobserved heterogenous effects for land rented in or rented out can be modelled as a random effects tobit model where the explanatory variables at time $t$ are

$x_{i t}=\left\{z_{i t}, g_{i, t-1}, r_{i 0}, z_{i}\right\}$

where $g_{i, t-1}=g\left(y_{i, t-1}\right)$ and $r_{i 0}=r\left(y_{i 0}\right)$. The latent variable model may be written as $y_{i t}^{*}=z_{i t} \gamma+g_{i, t-1} \rho+c_{i}+u_{i t}=z_{i t} \gamma+g_{i, t-1} \rho+\alpha_{0}+r_{i 0} \alpha_{1}+z_{i} \alpha_{2}+u_{i t}$

The analysis requires balanced panel data. Unbalanced panel data would require estimation of a different conditional distribution of $c_{i}$ for each configuration of the missing data that may be feasible for balanced sub-panels when there is no selection bias.

We calculated average partial effects (APEs) from the tobit models as;

$$
\overline{A P E}=\frac{\sum_{i} A P E_{i}}{N}=\frac{1}{N} \sum_{i}\left\{\frac{\partial E[y \mid X]}{\partial x_{j}}\right\}=\frac{1}{N} \sum_{i} \Phi(X \beta / \sigma) \beta_{j}
$$

Standard errors for APEs were calculated as;

$$
S E(\overline{A P E})=\left|\beta_{j}\right| \sqrt{\operatorname{Var}(\Phi(X \beta / \sigma))}
$$

\subsection{Data and variable inclusion}

We use a unique household panel data set from Tigray in northern Ethiopia, which consists of 400 households in 16 different communities. These communities are a subsample of communities included in an IFPRI community and household survey and covers the main variation in agroclimatic, market access and population densities in the highlands in the region. The households have been surveyed four times, covering the years 1997/98, 2000/01, 2002/03 and 2005/06 while land certification was implemented in all communities in 1998/99.

The requirement that all households need to be included in all years (balanced panel) reduced the sample size to close to 300 households. Dependent variables in the analyses are dummy variables for participation in the land rental market as landlords or tenants and land area 
rented out or rented in. Lagged dependent variables and initial year participation was included to deal with the initial conditions problem (Wooldridge 2005). Variable names and descriptions are presented in Table 1.

Hypothesis $\mathrm{H} 1$ is simply tested by assessing whether the probability and degree of participation in the land rental market by landlords has increased significantly over time and by assessing whether possession of land certificates was significantly and positively correlated with the probability and degree of participation in the land rental market. Furthermore, year dummies were included for the years after the land registration and certification to test whether market participation has increased after the reform. Although the land registration and certification can be seen as an exogenous policy change, we cannot be sure that receiving a land certificate at household level is totally random. We therefore used all available household and village characteristics to predict the "having a certificate" variable at household level (landcerp).

We tested hypothesis $\mathrm{H} 2$ by including the lagged dependent variables in the probit as well as tobit models while also controlling for unobservables by inclusion of the initial market participation and other exogenous variables. The same was done in the landlord-side and the tenant-side of the market.

Our hypothesis H3 was that the certificates increased the tenure security of (potential) female landlords such that they would become relatively more willing to rent out their land after the reform. We included sex of household head (hhsex) to test for gender differences in market participation and an interaction variable for sex of household head and the predicted having a land certificate (hhsexcerp) to assess whether female headed households receiving land certificates changed their land rental market participation. An interaction variable for sex of household head and years since certification (hhsexcrtyr) was included to assess how land rental market activity has a different pattern over time after the reform for female-headed households than for male-headed households.

To assess hypothesis $\mathrm{H} 4$, whether older households increased their market participation as landlords if they had certificates (because it increased their tenure security), we included an interacton variable (hhagecerp) between household age (age of head of household) and 
having a certificate (predicted). Our hypothesis indicates that its sign should be positive in the landlord model.

Testing of tenants' access and participation in the land rental market (H5) is following the same approach as for $\mathrm{H} 1$ in the probit and tobit models.

To test for a non-linear effect of the reform (hypotheses H6a and H6b) we tried alternative approaches, including year dummies and a variable representing the number of years since the reform was implemented (certyears) and another being the square of this variable (certyear2). With this latter formulation we dropped the year dummies for the last two periods due to collinearity problems. The second year dummy was included to test for the initial effect of the reform.

Hypothesis $\mathrm{H} 7$ was tested by including the interaction variable between initial land market participation and having a land certificate (llotOcerp $=$ llot $0 *$ landcerp and llitOcerp $=$ llit0 $*$ landcerp $)$.

Hypothesis $\mathrm{H} 8$ was tested by either including the share of households initially participating in the land rental market (villrmpart) or a dummy variable for villages with a share of more than $35 \%$ of the households participating in the land rental market (villrmpd $=1$ if villrmpart $>0.35$ and zero otherwise). Finally, we tested hypothesis H9 by including an interaction variable (vilpdcrtyr=villrmpd $*$ certyears). Several models had to be run to test the alternative hypotheses and to assess the robustness of the results with alternative specifications.

We also included a dummy variable for the communities that were most affected by the war with Eritrea in the second and third period (2000/01 and 2002/03). We expect the war to have had a negative effect on the land rental market. There is also a risk that the war has had a more widespread negative effect that could have reduced or delayed the effect of the land reform on land rental market development.

\section{Results and discussion}

\subsection{Descriptive analysis}

We present key summary statistics in Tables 2 and 3. In Table 2 we see the change over time for key household level variables. We see that the percentage of households that rented in 
land (tent) increased from $8 \%$ in 1997 to $30.5 \%$ in 2000 and then down to 27.9 and $26.5 \%$ in 2003 and 2006. The percentage of households renting out land (llord) increased from $23.7 \%$ in 1997 to $26.9 \%$ in 2000 and to 26 and $28.8 \%$ in 2003 and 2006. This seems to support our hypotheses $\mathrm{H} 1$ and $\mathrm{H} 5$. There appeared to be a stronger initial effect on the tenant side than on the landlord side but since the overall participation in the local land rental markets should be a zero-sum game, the dynamic pattern is not quite clear from our sample. The mean area leased in increased from 0.18 tsimdi $^{4}$ in 1997 to 0.77 tsimdi in 2000 and then down to 0.71 and 0.52 tsimdi in 2003 and 2006. Average area leased out increased from 0.52 tsimdi in 1997 to 0.73 tsimdi in $2000,0.79$ in 2003 and down to 0.74 tsimdi in 2006 . The percentage of the households with certificate increased from 0 in 1997 to $95.1 \%$ in 2000 and to $98.5 \%$ in 2003 and declined to $88.6 \%$ in 2006 . The reason for the reduction may be that some households have lost their certificate or due to inheritance (change in head of household) that also may have involved a subdivision of the land holding without receiving new certificate. The share of households that are female-headed increased from $12.5 \%$ in 1997 to $30.5 \%$ in 2006.

Table 3 characterises the households that either participate in the land market as landlords or tenants or do not participate in the land market and whether the characteristics have changed over time. We see that landlord households are significantly poorer in oxen, other livestock (tlu), male labour and female labour than tenants and households not participating in the land rental market, while they are not poorer in terms of land endowment (own_hold). Similarly tenant households were richer than nonpartipating households in oxen, other livestock and male labour endowment but not in female labour endowment while their land endowment was slightly higher. This pattern remained fairly stable over the years the data covered.

\subsection{Land reform and participation in the land rental market}

We present the results of the land rental market participation probit models in Table 4. These are the results of probit random effects models testing for state dependence (hypothesis $\mathrm{H} 2$ ) while controlling for unobserved heterogeneity. We first look at the landlord (lease out) participation model. We see that the lagged market participation variable (llord_t 1 ) is highly significant and positive indicating the presence of state dependence, in line with hypothesis $\mathrm{H} 2$. Earlier market participation as landlords is strongly correlated with being a landlord in later periods. When it comes to the land reform-related variables, we see that the predicted land certificate variable was significant at $5 \%$ level and with a positive sign. Households with

\footnotetext{
${ }^{4}$ One $t$ simdi is approximately 0.25 ha and is the area of land that a pair of oxen can cultivate in a day.
} 
certificate were more likely to rent out their land than households without certificate. This is in line with hypothesis H1.

Female-headed households and households with older heads of household were significantly (at 5 and 10\% levels) more likely to rent out their land, while more educated households and households with more oxen were significantly (at 10 and 1\% levels) less likely to rent out their land. Households with larger land endowment were significantly (at $0.1 \%$ level) more likely to rent out their land. The linear and quadratic years with certificate variables were significant at $10 \%$ level with negative and positive signs.

When we look at the tenant (land lease in) probit model (Table 4) we see that also here the lagged variable (tent_t 0$)$ was highly significant $(0.1 \%$ level) and had a positive sign demonstrating again the state dependence in the land rental market (hypothesis H2). Oxen ownership, other livestock and education had significant (1\%, 10\% and 5\% levels) and positive effects on market participation while female-headed households and households with older household heads were significantly ( $0.1 \%$ and $10 \%$ levels) less likely to rent in land. Own farm size had no significant effect on the probability of leasing in land while this variable was highly significant in the landlord model.

\subsection{Land reform and degree of participation in the land rental market}

The results of the household random effects tobit panel data models with state dependence, and controlling for unobserved heterogeneity, are presented in Tables 5 for the landlord side and in Table 6 for the tenant side.

\section{Land leased out models}

In order to test all our hypotheses and assess the robustness of the findings we specified four alternative models without and with different interaction variables. The first model (Lease out 1 ) is without interaction variables. The second model (Lease out 2) contains interaction variables between sex of household head and having certificate (hhsexcerp), sex of household head and years with certificate (hhsexcrtyr), and between age of household head and having certificate (hhagecerp). The third model (Lease out 3) contains interaction variables for initial year participation and having certificate (llot0cerp), for initial year participation and years with certificate (llot0crtyrs), and for share of village participating initially times having certificate (vilcerp). The squared years with certificate variable was taken out and replaced 
with year dummies for 2003 and 2006. The forth model (Lease out 4) is different from the previous model by having replaced the the village share of households initially participating in the land rental market (villrmpart) with the initial household land rental market participation times years with certificate variable (llotOcrtyr), a dummy for villages with high initial land rental market participation (villrmpd), and an interaction variable for the last variable and years with certificate (vilpdcrtyr).

We see from the Lease out 1 and Lease out 2 models in Table 5 that the sex of household head was highly significant and with a positive sign in both models, having land certificate (landcerp) was significant at $10 \%$ level only in the first model and insignificant in the second, while the interaction variable between sex of household head and having certificate (hhsexcerp) was significant at 5\% level and with a positive sign. We interpret this a support in favour of hypotheses $\mathrm{H} 1$ and $\mathrm{H} 3$; land certificates have stimulated landlords to rent out more land and this is more the case for female-headed households than for male-headed households. This finding is also supported by additional perception data that we have from the 2006 round survey which indicated that land certification has contributed to strengthen women's land rights, making them more willing to rent out land, and increasing their bargaining power in the land rental market. Also the interaction variable between sex of household head and years with certificate (hhsexcrtyr) was significant and with a negative sign. This means that although female household have increased their renting out activity, the amount of land they rent out has declined over time after the first initial increase. Further analysis is required to investigate the reasons for this. One possibility is that their welfare may have improved following the reform and they may then have become more able to farm the land themselves or they have become less dependent on and exposed to coersion by their inlaw tenants (Holden and Bezabih, Forthcoming).

To test hypothesis $\mathrm{H} 4$ that certificates increase tenure security of old households and therefore their willingness rent out land we can look at the results for the variable (hhagecerp) in Land lease model 2 in Table 5. The variable was significant at 5\% level and had a positive sign in line with our hypothesis H4. It appears therefore that the certificates have made femaleheaded and old household heads more willing to rent out their land, probably because the certificates have made them more tenure secure. This fits also with the anecdotal evidence (MUT 2003) and our perception data from 2006. 
We see that the lagged dependent variable, lagged area leased out (llo_t 1$)$, was highly significant and positive, demonstrating the importance of state dependence in the land rental market (hypothesis H2). This is the case also after we have controlled for unobserved heterogeneity by including the initial period land leased out area (llo_t 0$)$, which also is highly significant in all model specifications. We included the farm size (own_hold) variable, which usually is used to test for allocative efficiency of land rental markets (Bliss and Stern 1982; Skoufias 1995). With efficient adjustment this coefficient should be equal to +1 . As can be seen we find the coefficient to be about 0.17 and significantly (at $0.1 \%$ level) different from 0 but also significantly smaller than +1 . This together with the significant state dependence illustrates that landlords face significant transaction costs in the market.

The initial condition variables were highly significant in all the models and should control for unobservable household heterogeneity. The variables may, however, also have an observable effect that admittedly is confounded with the unobservable effect and therefore requires cautious interpretation. Relying on the assumption of linearity in parameters, we also introduced in the Lease out 3 model in Table 5 the interaction variable for initial market participation and receiving a certificate (llot0cerp). We found then that households that initially rented out land and had received a certificate were renting out significantly $(0.1 \%$ level) less land after they received the certificates. This may mean that households already in the market benefitted less from the certificate than others because they already had market access and more trustworthy partners (supporting hypothesis $\mathrm{H} 7$ ).

Our hypothesis $\mathrm{H} 8$ stated that land rental market activity increased most in communities with low share of participating households in the land rental market before the land reform. We used the villrmpart and villrmpd variables in the Lease out 3 and 4 models respectively to test it. We found somewhat surprisingly that both variables were significant and with a positive sign, causing us to reject hypothesis H8. This seems to imply that land rental market participation improved more in communities with higher level of initial participation. This result may also have implications for the next hypothesis, H9, which stated that having a land certificate had a more positive effect on land market participation in villages with low initial land rental market activity. We see from the Lease out 4 model that the villcerp variable was significant and with a positive sign, also rejecting our hypothesis 9. Having a certificate appeared to be more beneficial in communities with higher initial land rental market activity. 
Finally, we tested our hypothesis H10 that land rental market participation increased more over time in villages with low initial paticipation in the land rental market (due to higher transaction cost-reducing potential of the reforms in villages where activity was initially low). The sign of the vilcrtyr variable was negative and it was significant at $1 \%$ level in line with this hypothesis, signaling a declining effect of certification over time. We should, however, take the results of these interaction variables with a grind of salt as we rely on linearity assumptions. The AIC and BIC numbers in Table 5 also increase as we move from model 1 to 4.

We also see that oxen-ownership (oxen), male labour force (adumale) and education (hhedu) had negative effects on land leased-out. This implies that those who are poor in non-land resources rent out more land in line with findings in other studies in Ethiopia and Eritrea (Tikabo et al., 2007; Deininger et al., Forthcoming).

\section{Land leased in models}

The random effects tobit models for land leased in are presented in Table 6. Models 2 an 3 have included additional interaction variables. Also here we find that the lagged dependent variable is highly significant ( $1 \%$ and $0.1 \%$ levels) and with positive sign, confirming the state dependence in line with the nonconvex transaction cost hypothesis (H2) that also implies that the land rental market is characterised by allocative inefficiency. This can also be seen by the parameter on the farm size variable (own_hold) being insignificant and close to zero.

Having a land certificate appeared not to be important for tenants' access to land to rent in. What is more important for access is ownership of oxen and other livestock $(t l u)$ which were highly significant and contributed positively to area rented in while also education of household head had a positive effect but it was only significant at $10 \%$ level. On the other hand, female-headed households and households with old household heads rented in significantly less land. These households were more likely to be on the other side of the land rental market as we saw from the land lease out models.

From the Lease in 2 and 3 models in Table 6 we see that households that initially participated in the market and received land certificates (the llit0cerp-variable) reduced significantly their land leased in as compared to other households, indicating that households that initially did not participate may have benefited more by getting better access. 
The other interaction variables were not significant, except the interaction between initial leased in land and the number of years since certification (llit0crtyr) which only was significant at $10 \%$ level and with a positive sign, indicating an increasing trend in area rented in after certification.

Overall we saw from Table 3 that tenants are wealthier in terms of endowments of non-land resources while they are not particularly land-poor or land-rich. Earlier market participation appears important for access to land in the land rental market, in line with the findings for other emerging markets in Africa where trust and reputation play important roles (Fafchamps 2004).

\section{Average partial effects}

We calculated average partial effects (APEs) from the tobit models. The APEs for the land lease out and land lease in models (the first of the models in Tables 5 and 6) are presented in Tables 7 and 8 . We see from Table 7 that the APE for land area leased out was 0.526 for having a land certificate vs. not having a land certificate for the whole sample, while the APE for area leased in was 0.209 for having vs. not having a certificate. For the continuous variables we also see that APEs for the lagged dependent variables (llo_t 1 in Table 7 and lli_t 1 in Table 8) were substantially higher than the APEs for own holding. This indicates that there are significant non-convex transaction costs in the land rental market and that the shortterm response to own holding is limited. It also appears that the APEs for the lagged dependent variable and own holding are higher in the lease out (landlord) model than in the lease in (tenant) model. This is also in line with the hypothesis that tenants are rationed in the market.

To further look into the effects of land certificates over time we calculated the APEs of land certificate for land leased out for male vs. female-headed households that were participating in the land rental market or not and by year. The APEs are presented in Table 9. We see that the APEs are higher in the first year, higher for female-headed households than for maleheaded households and they are higher for households already participating in the market than for non-participants. This is also in line with the findings in the lease out models 2-4 in Table 5 with the interaction variables for sex of household head, having land certificate, and earlier market participation. It is evident that female-headed households have become more willing 
to rent out their land and they tend to rent out more land when they have a certificate. This fits well with the hypothesis that a land certificate increases tenure security of landowners and they have therefore become more willing to rent out their land when their desired cultivated area is lower than their own holding.

\section{Conclusion}

Our analysis of the panel data from Tigray has demonstrated a significant and positive effect of the land registration and certification reform that took place in the late 1990s on the amount of activity in the land rental market. The reform appears to have reduced transaction costs in the land rental market by making potential landlords more willing to rent out their land. It has therefore also become easier for (potential) tenants to access land to rent in. This is likely to be caused by female-headed households who received land certificates feeling more tenure secure and have therefore become less reluctant to rent out their land.

Recent changes in the land proclamation (law) imposing a restriction on the amount of land that households can lease out to maximum half of the land of households may become a threat to tenure security of poor households, like female-headed and old households, that lack the necessary non-land resources to farm their land efficiently. We recommend that this policy restriction is lifted because it is bad both for efficiency and equity.

The analyses demonstrate that transaction costs in the land rental market remain high and there should be room for reducing these by facilitating transactions at the local level. Care should be exercised when reforming land rental markets, however, to make sure that the benefits from the reforms are higher than the costs. A system for voluntary registration of land rental contracts may be better than the system with compulsory registration of all land rental contracts that is now attempted imposed by law. 
Table 1. Overview of variables used in the econometric analysis

\begin{tabular}{|c|c|}
\hline $\begin{array}{l}\text { Variable } \\
\text { name }\end{array}$ & Variable description \\
\hline tent & Participation as tentant in land rental market, $1=$ yes, $0=$ no \\
\hline tent_t1 & Lagged participation in land rental market as tenant, $1=$ yes, $0=$ no \\
\hline tent_t0 & Initial year participation in land rental market as tenant, $1=$ yes, $0=$ no \\
\hline llord & Participation as landlord in land rental market, $1=$ yes, $0=$ no \\
\hline llord_t1 & Lagged participation in land rental market as landlord, $1=$ yes, $0=$ no \\
\hline llord_t0 & Initial year participation in land rental market as landlord, $1=$ yes, $0=$ no \\
\hline 110 & Land leased out (in tsimdi, one tsimdi $=0.25 \mathrm{ha}$ ) \\
\hline lli & Land leased in (tsimdi) \\
\hline 1lo_t1 & Lagged land leased out \\
\hline 1lo_t0 & Initial year (before land reform) land leased out \\
\hline 1li_t1 & Lagged land leased in \\
\hline 1li_to & Initial year land leased in \\
\hline landcert & Household having land certificate, $1=y e s, 0=$ no \\
\hline landcerp & Predicted household having land certificate \\
\hline llot0cerp & Interaction of initial year land leased out and predicted having land certificate \\
\hline llot0crtyr & Interaction of initial year land leased out and years of having certificate \\
\hline llit0cerp & Interaction of initial year land leased in and predicted having land certificate \\
\hline llit0crtyr & Interaction of initial year land leased in and years of having certificate \\
\hline hhsex & Sex of household head, $1=$ female, $0=$ male \\
\hline hhsexcerp & Interaction of sex of household head and predicted having land certificate \\
\hline hhsexcrtyr & Interaction of sex of household head and years of having certificate \\
\hline conflict & $\begin{array}{l}\text { Dummy variable for communities close to the war zone during war with } \\
\text { Etritrea, } 1=\text { conflict area, } 0=\text { otherwise }\end{array}$ \\
\hline hhedu & Education of household head, $0=$ no eduction, $1=$ primary school, \\
\hline hhage & Age of head of household, years \\
\hline hhagecerp & Interaction of age of household head and predicted having land certificate \\
\hline adufem & Number of adult females in household \\
\hline adumale & Number of adult males in household \\
\hline tlu & Tropical livestock units \\
\hline oxen & Number of oxen \\
\hline $\begin{array}{l}\mathrm{d} 2000, \\
\mathrm{~d} 2003, \mathrm{~d} 2006\end{array}$ & Dummies for years \\
\hline certyears & Number of years since land certification was implemented \\
\hline certyear2 & Square of number of years since land certification was implemented \\
\hline villrmpart & $\begin{array}{l}\text { Share of households in village initially participating in land rental market } \\
(1997-98)\end{array}$ \\
\hline vilcerp & $\begin{array}{l}\text { Interaction variable for having certificate and living in village with high initial } \\
\text { land rental market activity (villrmpart*landcerp) }\end{array}$ \\
\hline villrmpd & $\begin{array}{l}\text { Dummy variable }=1 \text { for villages with high initial land rental market activity } \\
(>35 \% \text { participating), zero for other villages }\end{array}$ \\
\hline vilpdcrtyr & $\begin{array}{l}\text { Interaction variable for different dynamic effect in villages with high land } \\
\text { rental market activity (villrmpd*certyears) }\end{array}$ \\
\hline
\end{tabular}



Table 2. Summary statistics for key variables

\begin{tabular}{|c|c|c|c|c|c|c|c|c|c|c|c|}
\hline ear & tent & llord & $11 i$ & 110 & landcert & hhsex & oxen & tlu & adufem & adumale & own_hold \\
\hline 1997 & .0811688 & .237013 & .1826299 & .5154221 & 0 & .127451 & .9673203 & 1.713399 & 1.160131 & 1.24183 & $\begin{array}{l}34.590723 \\
\end{array}$ \\
\hline 2000 & .3051948 & .2694805 & .7662886 & .7237571 & .9512987 & .1140065 & .7597403 & 1.75 & 1.276873 & 1.387622 & 24.555479 \\
\hline 2003 & .2792208 & .2597403 & .7090395 & .7926136 & .9854015 & .262987 & .8279221 & 2.544156 & 1.256494 & 1.311688 & $8 \quad 4.101607$ \\
\hline 2006 & .2647059 & .2875817 & .5156291 & .7389069 & .8856209 & .3056478 & .9069767 & 2.83887 & 1.375415 & 1.415282 & $2 \quad 3.846889$ \\
\hline Total & .2325203 & .2634146 & .5434419 & .6925998 & .6973244 & .2021277 & .8650859 & 2.208831 & 1.266776 & 1.338789 & 94.274111 \\
\hline
\end{tabular}


Table 3. Summary statistics by year for key endowment variables of landlord, nonparticipant and tenant households.

\begin{tabular}{|c|c|c|c|c|c|c|c|}
\hline tenure & stats & oxen & tlu & adumale & adufem & adulteql & own_hold \\
\hline \multirow[t]{2}{*}{ Landlord } & mean & 0.58 & 1.07 & 1.03 & 1.20 & 3.83 & 4.72 \\
\hline & $\operatorname{se}(\operatorname{mean})$ * & 0.10 & 0.18 & 0.12 & 0.07 & 0.23 & 0.38 \\
\hline \multirow{2}{*}{ Nonpart. } & mean & 1.04 & 1.78 & 1.29 & 1.16 & 4.25 & 4.39 \\
\hline & se (mean) & 0.06 & 0.12 & 0.06 & 0.04 & 0.12 & 0.40 \\
\hline \multirow[t]{2}{*}{ Tenant } & mean & 1.48 & 3.02 & 1.48 & 1.08 & 4.52 & 5.90 \\
\hline & se (mean) & 0.19 & 0.54 & 0.22 & 0.06 & 0.39 & 1.34 \\
\hline \multirow[t]{2}{*}{ Total } & mean & 0.97 & 1.71 & 1.24 & 1.16 & 4.18 & 4.59 \\
\hline & se (mean) & 0.05 & 0.11 & 0.05 & 0.03 & 0.11 & 0.31 \\
\hline \multicolumn{8}{|c|}{ year $=2000$} \\
\hline \multirow[t]{2}{*}{ Landlord } & mean & 0.36 & 0.91 & 1.06 & 1.22 & 4.02 & 4.65 \\
\hline & se (mean) & 0.07 & 0.14 & 0.12 & 0.08 & 0.25 & 0.36 \\
\hline \multirow[t]{2}{*}{ Nonpart. } & mean & 0.70 & 1.61 & 1.41 & 1.32 & 4.64 & 4.16 \\
\hline & se (mean) & 0.08 & 0.14 & 0.09 & 0.07 & 0.16 & 0.23 \\
\hline \multirow[t]{2}{*}{ Tenant } & mean & 1.17 & 2.64 & 1.62 & 1.27 & 5.13 & 5.06 \\
\hline & se (mean) & 0.11 & 0.25 & 0.10 & 0.07 & 0.19 & 0.38 \\
\hline \multirow[t]{2}{*}{ Total } & mean & 0.76 & 1.75 & 1.39 & 1.28 & 4.63 & 4.56 \\
\hline & se (mean) & 0.05 & 0.11 & 0.06 & 0.04 & 0.11 & 0.18 \\
\hline \multicolumn{8}{|c|}{ year $=2003$} \\
\hline \multirow[t]{2}{*}{ Landlord } & mean & 0.24 & 1.07 & 0.78 & 1.37 & 3.54 & 4.45 \\
\hline & se (mean) & 0.06 & 0.20 & 0.10 & 0.09 & 0.23 & 0.32 \\
\hline \multirow[t]{2}{*}{ Nonpart. } & mean & 0.75 & 2.27 & 1.32 & 1.34 & 4.56 & 3.81 \\
\hline & se (mean) & 0.06 & 0.19 & 0.08 & 0.07 & 0.16 & 0.18 \\
\hline \multirow[t]{2}{*}{ Tenant } & mean & 1.49 & 4.31 & 1.77 & 1.01 & 5.19 & 4.29 \\
\hline & se (mean) & 0.11 & 0.34 & 0.10 & 0.07 & 0.17 & 0.30 \\
\hline \multirow[t]{2}{*}{ Total } & mean & 0.83 & 2.54 & 1.31 & 1.26 & 4.48 & 4.10 \\
\hline & se (mean) & 0.05 & 0.16 & 0.06 & 0.05 & 0.11 & 0.15 \\
\hline \multicolumn{8}{|c|}{ year $=2006$} \\
\hline \multirow[t]{2}{*}{ Landlord } & mean & 0.43 & 1.53 & 1.01 & 1.12 & 3.60 & 4.23 \\
\hline & se (mean) & 0.08 & 0.23 & 0.13 & 0.09 & 0.23 & 0.30 \\
\hline \multirow[t]{2}{*}{ Nonpart. } & mean & 0.87 & 2.69 & 1.44 & 1.48 & 4.68 & 3.47 \\
\hline & se (mean) & 0.08 & 0.20 & 0.10 & 0.08 & 0.19 & 0.22 \\
\hline \multirow[t]{2}{*}{ Tenant } & mean & 1.45 & 4.43 & 1.77 & 1.45 & 5.32 & 4.12 \\
\hline & se (mean) & 0.10 & 0.40 & 0.12 & 0.08 & 0.20 & 0.35 \\
\hline \multirow[t]{2}{*}{ Total } & mean & 0.91 & 2.84 & 1.42 & 1.38 & 4.56 & 3.85 \\
\hline & se (mean) & 0.06 & 0.17 & 0.07 & 0.05 & 0.13 & 0.16 \\
\hline
\end{tabular}

* se(mean) is the standard error of the mean 
Table 4. Random effects panel probit models with unobserved heterogeneity and state dependence

\begin{tabular}{|c|c|c|}
\hline & Lease Out & Lease In \\
\hline llord_t1 & $\begin{array}{l}1.250 * \star \star \star \\
(0.13)\end{array}$ & \\
\hline llord_t0 & $\begin{array}{l}0.753 * \star \star \star \\
(0.14)\end{array}$ & \\
\hline tent_t1 & & $\begin{array}{l}0.928 * \star \star \star \\
(0.13)\end{array}$ \\
\hline tent_to & & $\begin{array}{l}0.740 * \star \star \star \\
(0.18)\end{array}$ \\
\hline landcerp & $\begin{array}{l}2.120 * \star \\
(1.05)\end{array}$ & $\begin{array}{l}1.084 \\
(0.96)\end{array}$ \\
\hline conflict & $\begin{array}{r}-0.139 \\
(0.14)\end{array}$ & $\begin{array}{r}-0.066 \\
(0.13)\end{array}$ \\
\hline hhsex & $\begin{array}{l}0.317 \star \star \\
(0.14)\end{array}$ & $\begin{array}{l}-0.740 * \star \star \star \\
(0.18)\end{array}$ \\
\hline hhedu & $\begin{array}{l}-0.155^{\star} \\
(0.08)\end{array}$ & $\begin{array}{l}0.144 * \star \\
(0.07)\end{array}$ \\
\hline hhage & $\begin{array}{l}0.005^{\star} \\
(0.00)\end{array}$ & $\begin{array}{l}-0.007 \star \\
(0.00)\end{array}$ \\
\hline adufem & $\begin{array}{l}-0.052 \\
(0.07)\end{array}$ & $\begin{array}{l}-0.150 * \star \\
(0.07)\end{array}$ \\
\hline adumale & $\begin{array}{l}-0.088 \\
(0.06)\end{array}$ & $\begin{array}{r}0.088 \\
(0.05)\end{array}$ \\
\hline oxen & $\begin{array}{l}-0.254 * \star \star \\
(0.09)\end{array}$ & $\begin{array}{l}0.238 * \star \star \\
(0.08)\end{array}$ \\
\hline tlu & $\begin{array}{c}0.004 \\
(0.03)\end{array}$ & $\begin{array}{l}0.056 * \\
(0.03)\end{array}$ \\
\hline own_hold & $\begin{array}{l}0.042^{\star \star \star \star} \\
(0.01)\end{array}$ & $\begin{array}{r}-0.009 \\
(0.02)\end{array}$ \\
\hline$d 2000$ & $\begin{array}{c}-0.544 \\
(0.42)\end{array}$ & $\begin{array}{r}0.352 \\
(0.39)\end{array}$ \\
\hline$d 2003$ & D & D \\
\hline$d 2006$ & D & D \\
\hline certyears & $\begin{array}{l}-0.684^{\star} \\
(0.36)\end{array}$ & $\begin{array}{r}-0.058 \\
(0.33)\end{array}$ \\
\hline certyear2 & $\begin{array}{l}0.060 * \\
(0.03)\end{array}$ & $\begin{array}{r}0.007 \\
(0.03)\end{array}$ \\
\hline _cons & $\begin{array}{l}-1.598 * \star \star \star \\
(0.25)\end{array}$ & $\begin{array}{l}-1.804 * \star \star \star \\
(0.26)\end{array}$ \\
\hline lnsig2u_cons & $\begin{array}{l}-3.600 * \star \star \star \\
(0.48)\end{array}$ & $\begin{array}{l}-3.564 * \star \star \star \\
(0.60)\end{array}$ \\
\hline Prob > chi2 & 0.000 & 0.000 \\
\hline Number of obs. & 1219 & 1219 \\
\hline
\end{tabular}

Note: Standard errors in parentheses. $*$ significant at $10 \%$;* significant at 5\%; $* * *$ significant at $1 \%, * * * *$ significant at $0.1 \%$. $\mathrm{D}=$ dropped by Stata due to collinearity 
Table 5. Random effects tobit panel data models with state dependency and unobservable heterogeneity for land leased out: Alternative model specifications without and with interaction variables

\begin{tabular}{|c|c|c|c|c|}
\hline 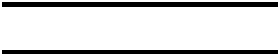 & Lease out 1 & Lease out 2 & Lease out 3 & Lease out 4 \\
\hline$\overline{110 \_t 1}$ & $\begin{array}{l}0.646 \star \star \star \star \\
(0.08)\end{array}$ & $\begin{array}{l}0.659 * \star \star \star \\
(0.08)\end{array}$ & $\begin{array}{l}0.507 \star \star \star \star \\
(0.09)\end{array}$ & $\begin{array}{l}0.536 * \star \star \star \\
(0.09)\end{array}$ \\
\hline 11o_to & $\begin{array}{l}0.652 * \star \star \star \\
(0.09)\end{array}$ & $\begin{array}{l}0.630 * \star \star \star \\
(0.09)\end{array}$ & $\begin{array}{l}1.077 * \star \star \star \\
(0.16)\end{array}$ & $\begin{array}{l}1.105 * \star \star \star \\
(0.15)\end{array}$ \\
\hline landcerp & $\begin{array}{l}3.878 * \\
(2.35)\end{array}$ & $\begin{array}{r}1.271 \\
(2.57)\end{array}$ & $\begin{array}{r}3.159 \\
(2.62)\end{array}$ & $\begin{array}{r}2.331 \\
(2.58)\end{array}$ \\
\hline conflict & $\begin{array}{l}-0.360 \\
(0.33)\end{array}$ & $\begin{array}{c}-0.324 \\
(0.33)\end{array}$ & $\begin{array}{c}0.428 \\
(0.36)\end{array}$ & $\begin{array}{l}0.639 \star \\
(0.37)\end{array}$ \\
\hline hhsex & $\begin{array}{l}1.111 * \star \star \star \\
(0.31)\end{array}$ & $\begin{array}{l}1.198 * * \\
(0.58)\end{array}$ & $\begin{array}{l}1.246 * \star \\
(0.58)\end{array}$ & $\begin{array}{l}1.123 * \\
(0.58)\end{array}$ \\
\hline hhedu & $\begin{array}{l}-0.574 \star \star \star \\
(0.19)\end{array}$ & $\begin{array}{l}-0.546 * \star \star \\
(0.20)\end{array}$ & $\begin{array}{l}-0.403 * \star \\
(0.19)\end{array}$ & $\begin{array}{l}-0.403 * * \\
(0.19)\end{array}$ \\
\hline hhage & $\begin{array}{l}0.006 \\
(0.01)\end{array}$ & $\begin{array}{l}-0.022 \\
(0.02)\end{array}$ & $\begin{array}{l}-0.023 \\
(0.02)\end{array}$ & $\begin{array}{c}-0.022 \\
(0.02)\end{array}$ \\
\hline adufem & $\begin{array}{c}-0.061 \\
(0.15)\end{array}$ & $\begin{array}{r}-0.061 \\
(0.15)\end{array}$ & $\begin{array}{c}-0.113 \\
(0.15)\end{array}$ & $\begin{array}{l}-0.109 \\
(0.15)\end{array}$ \\
\hline adumale & $\begin{array}{l}-0.348 * \star \star \\
(0.13)\end{array}$ & $\begin{array}{l}-0.313 * * \\
(0.13)\end{array}$ & $\begin{array}{l}-0.271 * * \\
(0.13)\end{array}$ & $\begin{array}{l}-0.274 * \star \\
(0.13)\end{array}$ \\
\hline tlu & $\begin{array}{l}-0.040 \\
(0.07)\end{array}$ & $\begin{array}{l}-0.050 \\
(0.07)\end{array}$ & $\begin{array}{l}-0.056 \\
(0.07)\end{array}$ & $\begin{array}{l}-0.063 \\
(0.07)\end{array}$ \\
\hline oxen & $\begin{array}{l}-0.652 * \star \star \\
(0.21)\end{array}$ & $\begin{array}{l}-0.663 * \star * \\
(0.21)\end{array}$ & $\begin{array}{l}-0.641 * \star \star \\
(0.20)\end{array}$ & $\begin{array}{l}-0.616 * \star \star \\
(0.20)\end{array}$ \\
\hline own_hold & $\begin{array}{l}0.169 * \star \star \star \\
(0.03)\end{array}$ & $\begin{array}{l}0.175 * \star \star * \\
(0.03)\end{array}$ & $\begin{array}{l}0.158 * \star \star * \\
(0.03)\end{array}$ & $\begin{array}{l}0.157 * \star \star \star \\
(0.03)\end{array}$ \\
\hline$d 2000$ & $\begin{array}{c}-0.772 \\
(0.94)\end{array}$ & $\begin{array}{l}-0.546 \\
(0.93)\end{array}$ & $\begin{array}{l}-3.132 \star \\
(1.76)\end{array}$ & $\begin{array}{l}-3.415^{\star} \\
(1.81)\end{array}$ \\
\hline certyears & $\begin{array}{c}-1.082 \\
(0.81)\end{array}$ & $\begin{array}{r}-0.977 \\
(0.80)\end{array}$ & $\begin{array}{l}-0.398 \\
(0.27)\end{array}$ & $\begin{array}{l}-0.327 \\
(0.27)\end{array}$ \\
\hline certyear2 & $\begin{array}{c}0.092 \\
(0.07)\end{array}$ & $\begin{array}{c}0.094 \\
(0.07)\end{array}$ & & \\
\hline hhsexcerp & & $\begin{array}{l}1.717 \star \star \\
(0.86)\end{array}$ & $\begin{array}{l}1.839 * \star \\
(0.84)\end{array}$ & $\begin{array}{l}2.042 * \star \\
(0.84)\end{array}$ \\
\hline hhsexcrtyr & & $\begin{array}{l}-0.307 \star \star \star \\
(0.11)\end{array}$ & $\begin{array}{l}-0.312 \star \star \star \\
(0.10)\end{array}$ & $\begin{array}{l}-0.326 * \star \star \\
(0.10)\end{array}$ \\
\hline hhagecerp & & $\begin{array}{l}0.038 * \star \\
(0.02)\end{array}$ & $\begin{array}{l}0.043 * \star \\
(0.02)\end{array}$ & $\begin{array}{l}0.042 * * \\
(0.02)\end{array}$ \\
\hline$d 2003$ & D & D & $\begin{array}{l}-2.371 * \star \\
(1.07)\end{array}$ & $\begin{array}{l}-2.571 * \star \\
(1.10)\end{array}$ \\
\hline 11 ot 0 cerp & & & $\begin{array}{l}-0.674 * * \star * \\
(0.16)\end{array}$ & $\begin{array}{l}-0.907 * \star \star * \\
(0.21)\end{array}$ \\
\hline villrmpart & & & $\begin{array}{l}3.304 * \star \star \\
(1.26)\end{array}$ & \\
\hline vilcerp & & & $\begin{array}{r}0.504 \\
(1.52)\end{array}$ & $\begin{array}{l}4.339 * \star \star \\
(1.34)\end{array}$ \\
\hline llot0crtyr & & & & $\begin{array}{r}0.035 \\
(0.03)\end{array}$ \\
\hline villrmpd & & & & $\begin{array}{l}1.003 * \star \\
(0.43)\end{array}$ \\
\hline vilpdertyr & & & & $\begin{array}{l}-0.216 * \star \star \\
(0.08)\end{array}$ \\
\hline _cons & $\begin{array}{l}-3.249 * \star \star \star \\
(0.55)\end{array}$ & $\begin{array}{l}-1.907 * * \\
(0.83)\end{array}$ & $\begin{array}{l}-3.272 * \star \star \star \\
(0.95)\end{array}$ & $\begin{array}{l}-2.776 * \star \star \\
(0.89)\end{array}$ \\
\hline sigma_u_cons & $\begin{array}{l}0.028 * * * * \\
(0.00)\end{array}$ & $\begin{array}{l}0.033 * * * * \\
(0.00)\end{array}$ & $\begin{array}{l}0.517 * * * * \\
(0.13)\end{array}$ & $\begin{array}{l}0.464 * * * * \\
(0.13)\end{array}$ \\
\hline sigma_e_cons & $\begin{array}{l}2.741 * \star \star \star \\
(0.12)\end{array}$ & $\begin{array}{l}2.716 * \star \star \star \\
(0.12)\end{array}$ & $\begin{array}{l}2.560 * \star \star \star \\
(0.12)\end{array}$ & $\begin{array}{l}2.563 * \star \star \star \\
(0.12)\end{array}$ \\
\hline Prob > chi2 & 0.000 & 0.000 & 0.000 & 0.000 \\
\hline aic & 2016.163 & 2030.255 & 2102.002 & 2104.227 \\
\hline bic & 2108.067 & 2137.477 & 2224.541 & 2236.977 \\
\hline Number of obs. & 1219 & 1219 & 1219 & 1219 \\
\hline
\end{tabular}

Note: Standard errors in parentheses. $*$ significant at 10\%; ** significant at 5\%; *** significant at $1 \%, * * * *$ significant at $0.1 \%$. $\mathrm{D}=$ dropped by Stata due to collinearity 
Table 6. Random effects tobit panel data models with state dependency and unobservable heterogeneity for land leased in: Alternative model specifications without and with interaction variables

\begin{tabular}{|c|c|c|c|}
\hline & Lease in 1 & Lease in 2 & Lease in 3 \\
\hline$\overline{l l i \_t 1}$ & $\begin{array}{l}0.351 * \star \star \\
(0.11)\end{array}$ & $\begin{array}{l}0.329 * \star \star \star \\
(0.09)\end{array}$ & $\begin{array}{l}0.361^{\star \star \star \star} \\
(0.09)\end{array}$ \\
\hline lli_to & $\begin{array}{l}0.630 * \star \star * \\
(0.16)\end{array}$ & $\begin{array}{l}1.662^{\star \star \star *} \\
(0.23)\end{array}$ & $\begin{array}{l}1.654 * \star \star \star \\
(0.24)\end{array}$ \\
\hline landcerp & $\begin{array}{r}2.674 \\
(2.72)\end{array}$ & $\begin{array}{r}2.004 \\
(2.50)\end{array}$ & $\begin{array}{r}2.252 \\
(2.51)\end{array}$ \\
\hline conflict & $\begin{array}{r}0.027 \\
(0.37)\end{array}$ & $\begin{array}{r}-0.110 \\
(0.36)\end{array}$ & $\begin{array}{r}-0.123 \\
(0.38)\end{array}$ \\
\hline hhsex & $\begin{array}{l}-2.259 * \star \star \star \\
(0.52)\end{array}$ & $\begin{array}{l}-2.200 * \star \star \star \\
(0.48)\end{array}$ & $\begin{array}{l}-2.252 * \star \star \star \\
(0.48)\end{array}$ \\
\hline hhedu & $\begin{array}{l}0.324 * \\
(0.19)\end{array}$ & $\begin{array}{l}0.312^{\star} \\
(0.17)\end{array}$ & $\begin{array}{l}0.321 * \\
(0.17)\end{array}$ \\
\hline hhage & $\begin{array}{l}-0.030 * \star \star \\
(0.01)\end{array}$ & $\begin{array}{l}-0.036 * \star \star \star \\
(0.01)\end{array}$ & $\begin{array}{l}-0.035 * \star \star \star \\
(0.01)\end{array}$ \\
\hline adufem & $\begin{array}{r}-0.208 \\
(0.18)\end{array}$ & $\begin{array}{r}-0.211 \\
(0.17)\end{array}$ & $\begin{array}{l}-0.194 \\
(0.17)\end{array}$ \\
\hline adumale & $\begin{array}{r}0.226 \\
(0.15)\end{array}$ & $\begin{array}{r}0.221 \\
(0.14)\end{array}$ & $\begin{array}{l}0.199 \\
(0.14)\end{array}$ \\
\hline tlu & $\begin{array}{l}0.202^{\star \star \star} \\
(0.07)\end{array}$ & $\begin{array}{l}0.223 * \star \star \\
(0.07)\end{array}$ & $\begin{array}{l}0.219 * \star \star \\
(0.07)\end{array}$ \\
\hline oxen & $\begin{array}{l}0.676 * \star \star \star \\
(0.19)\end{array}$ & $\begin{array}{l}0.665^{\star \star \star \star *} \\
(0.19)\end{array}$ & $\begin{array}{l}0.683 * \star \star \star \\
(0.19)\end{array}$ \\
\hline own_hold & $\begin{array}{c}0.014 \\
(0.04)\end{array}$ & $\begin{array}{r}-0.005 \\
(0.04)\end{array}$ & $\begin{array}{r}-0.010 \\
(0.04)\end{array}$ \\
\hline$d 2000$ & $\begin{array}{r}0.700 \\
(1.09)\end{array}$ & $\begin{array}{r}2.033 \\
(1.86)\end{array}$ & $\begin{array}{r}1.517 \\
(1.97)\end{array}$ \\
\hline certyears & $\begin{array}{r}0.049 \\
(0.94)\end{array}$ & $\begin{array}{r}0.197 \\
(0.28)\end{array}$ & $\begin{array}{r}0.156 \\
(0.30)\end{array}$ \\
\hline certyear2 & $\begin{array}{r}-0.006 \\
(0.08)\end{array}$ & & \\
\hline$d 2003$ & $\mathrm{D}$ & $\begin{array}{r}0.853 \\
(1.14)\end{array}$ & $\begin{array}{r}0.536 \\
(1.20)\end{array}$ \\
\hline llit0cerp & & $\begin{array}{l}-1.798 * \star \star \star \\
(0.28)\end{array}$ & $\begin{array}{l}-2.324 * \star \star \star \\
(0.41)\end{array}$ \\
\hline villrmpart & & $\begin{array}{r}0.955 \\
(0.72)\end{array}$ & \\
\hline vilcerp & & & $\begin{array}{r}1.763 \\
(1.52)\end{array}$ \\
\hline littocrtyr & & & $\begin{array}{l}0.113 * \\
(0.06)\end{array}$ \\
\hline villrmpd & & & $\begin{array}{r}0.119 \\
(0.59)\end{array}$ \\
\hline vilpdertyr & & & $\begin{array}{r}-0.126 \\
(0.10)\end{array}$ \\
\hline _cons & $\begin{array}{l}-4.534 * \star \star \star \\
(0.73)\end{array}$ & $\begin{array}{l}-5.106 * \star \star \star \\
(0.73)\end{array}$ & $\begin{array}{l}-4.857 \star \star \star \star \\
(0.78)\end{array}$ \\
\hline sigma_u_cons & $\begin{array}{l}1.162 * * * * \\
(0.30)\end{array}$ & $\begin{array}{l}0.591 * \star * \star \\
(0.10)\end{array}$ & $\begin{array}{l}0.485 * \star * * \\
(0.09)\end{array}$ \\
\hline sigma_e_cons & $\begin{array}{l}2.854 * \star \star * \\
(0.16)\end{array}$ & $\begin{array}{l}2.820 * \star \star \star \\
(0.14)\end{array}$ & $\begin{array}{l}2.839 * \star \star \star \\
(0.14)\end{array}$ \\
\hline Prob > chi2 & 0.000 & 0.000 & 0.000 \\
\hline aic & 2019.458 & 1983.859 & 1988.066 \\
\hline bic & 2111.362 & 2085.974 & 2105.500 \\
\hline Number of obs. & 1219 & 1219 & 1219 \\
\hline
\end{tabular}

Note: Standard errors in parentheses. * significant at 10\%; ** significant at 5\%; $* * *$ significant at $1 \%, * * * *$ significant at $0.1 \%$. D $=$ dropped by Stata due to collinearity 
Table 7. Average partial effects from tobit model "Lease out 1".

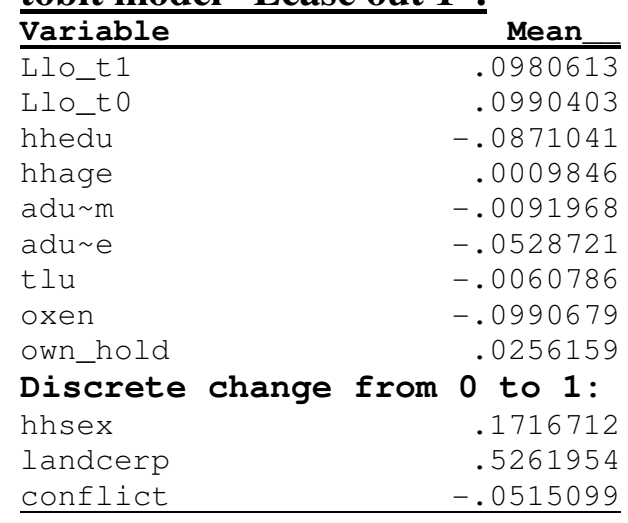

Table 8. Average partial effects from tobit model "Lease in 1".

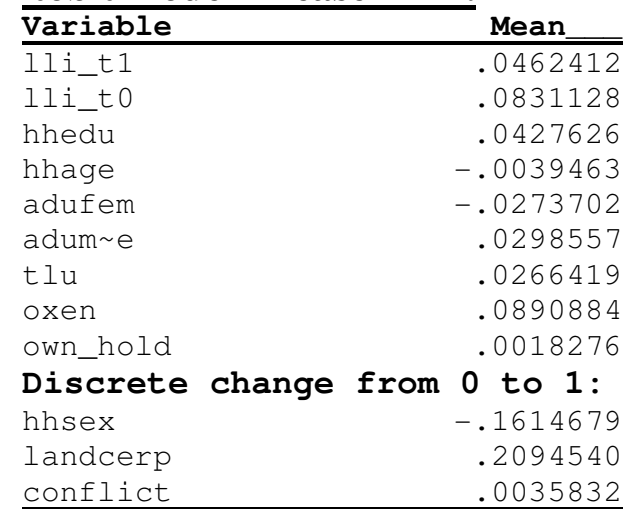


Table 9. Average partial effects of land certificate on land leased out for male- and female-headed households that are non-participant and participant households in the rental market by year

\begin{tabular}{|c|c|c|c|c|c|}
\hline \multicolumn{2}{|c|}{ Male-headed households } & 1997 & 2000 & 2003 & 2006 \\
\hline \multirow[t]{5}{*}{ Non-participants } & APE & 0.433 & 0.06 & 0.013 & 0.037 \\
\hline & $\mathrm{SD}$ & 0.757 & 0.335 & 0.124 & 0.27 \\
\hline & $\mathrm{N}$ & 215 & 216 & 186 & 162 \\
\hline & $\mathrm{SE}$ & 0.052 & 0.023 & 0.009 & 0.021 \\
\hline & t-value & 8.368 & 2.626 & 1.426 & 1.739 \\
\hline \multirow[t]{5}{*}{ Participants } & $\mathrm{APE}$ & 2.638 & 0.721 & 0.902 & 0.734 \\
\hline & $\mathrm{SD}$ & 1.245 & 1.441 & 1.438 & 1.404 \\
\hline & $\mathrm{N}$ & 51 & 56 & 41 & 45 \\
\hline & SE & 0.176 & 0.194 & 0.227 & 0.212 \\
\hline & t-value & 14.983 & 3.711 & 3.967 & 3.468 \\
\hline \multicolumn{6}{|c|}{ Female-headed households } \\
\hline \multirow[t]{5}{*}{ Non-participants } & $\mathrm{APE}$ & 2.294 & 0.234 & 0.358 & 0.233 \\
\hline & $\mathrm{SD}$ & 0.832 & 0.51 & 0.859 & 0.691 \\
\hline & $\mathrm{N}$ & 17 & 8 & 42 & 51 \\
\hline & $\mathrm{SE}$ & 0.208 & 0.193 & 0.134 & 0.098 \\
\hline & t-value & 11.029 & 1.214 & 2.669 & 2.384 \\
\hline \multirow[t]{5}{*}{ Participants } & $\mathrm{APE}$ & 3.538 & 1.069 & 1.118 & 1.559 \\
\hline & $\mathrm{SD}$ & 0.533 & 1.238 & 1.216 & 1.312 \\
\hline & $\mathrm{N}$ & 22 & 27 & 39 & 41 \\
\hline & $\mathrm{SE}$ & 0.116 & 0.243 & 0.197 & 0.207 \\
\hline & t-value & 30.419 & 4.403 & 5.668 & 7.515 \\
\hline
\end{tabular}

\section{References}

C. Bell and C. Sussangkarn (1988), 'Rationing and adjustment in the market for tenancies: The behavior of landowning households in Thanjavur district', American Journal of Agricultural Economics (November).

M. Bezabih and S. T. Holden (2006), 'Tenure Insecurity, Transaction Csots in the Land Lease Market and their Implications for Gendered Productivity Differentials', in 26th International Conference of the International Association of Agricultural Economists, Brisbane, Australia: International Association of Agricultural Economists.

C. J. Bliss and N. H. Stern (1982), Palanapur: The Economy of an Indian Village, Delhi and New York: Oxford University Press.

K. Deininger, D. A. Ali, S. T. Holden and J. Zevenbergen (2007), 'Rural land certification in Ethiopia: Process, initial impact, and implications for other African countries', in World Bank Policy Research Working Paper 4218: The World Bank.

K. Deininger, D. Ayalew and T. Alemu (Forthcoming), 'Adjustment through the land rental market: Transaction costs and tenure insecurity in rural Ethiopia', in Holden, S. T., Otsuka, K. and Place, F., eds., The Emergence of Land Markets in Africa: Assessing the Impacts on Poverty and Efficiency: RFF Press.

K. Deininger, D. Ayalew and T. Alemu (Forthcoming), 'Adjustment through the land rental market: Transaction costs and tenure insecurity in rural Ethiopia', in Holden, S. T., Otsuka, K. and Place, F., eds., The Emergence of Land Markets in Africa: Assessing the Impacts on Poverty and Efficiency: RFF Press.

M. Fafchamps (2004), Market Institutions in Sub-Saharan Africa, Cambridge, Massachusettes \& London: The MIT Press. 
E. Field and M. Torero (2003), 'Do Property Titles Increase Credit Access Among the Urban Poor? Evidence from a Nationwide Titling Program', in.

F. Finan, E. Sadoulet and A. de Janvry (2005), 'Measuring the poverty reduction potential of land in rural Mexico', Journal of Development Economics 77(1): 27-55.

H. Ghebru and S. T. Holden (Forthcoming), 'Factor Market Imperfections and Rural Land Rental Markets in Northern Ethiopian Highlands', in Holden, S. T., Otsuka, K. and Place, F., eds., The Emergence of Land Markets in Africa: Assessing the Impacts on Poverty and Efficiency: RFF Press.

M. Haile, W. Witten, K. Abraha, S. Fissha, A. Kebede, G. Kassa and G. Reda (2005), 'Land Registration in Tigray, Northern Ethiopia', in Securing Land Rights in Africa Research Report 2: IIED.

S. T. Holden and M. Bezabih (Forthcoming), 'Why is land productivity lower on land rented out by female-headed households?' in Holden, S. T., Otsuka, K. and Place, F., eds., The Emergence of Land Markets in Africa: Assessing the Impacts on Poverty and Efficiency: RFF Press.

S. T. Holden and H. Ghebru (2005), 'Kinship, Transaction Costs and Land Rental Market Participation', in Working Paper, Ås.

T. Mitchell (2005), 'The Work of Economics: How a Discipline Makes a World', European Journal of Sociology 45(2): 297-320.

MUT (2003), 'Securing land rights in Africa: Can land registration serve the poor?' in Interim Report of Mekelle University Team, Mekelle, Tigray, Ethiopia: Mekelle University.

J. Pender and M. Fafchamps (2006), 'Land Lease Markets and Agricultural Efficiency in Ethiopia', Journal of African Economies 15(2): 251-284.

M. Ravallion (in press), 'Evaluating Anti-Poverty Programs.' in R.E. Evenson and Schultz, T. P., eds., Handbook of Agricultural Economics Volume 4, Amsterdam: North-Holland.

E. Skoufias (1995), 'Household Resources, Transactions Costs, and Adjustment Through Land Tenancy', Land Economics 71(1): 42-56.

M. Tadesse, S. T. Holden and R. Øygard (Forthcoming), 'Cost-sharing and Endogenous Land Rental Contract Choice: Theory, and Evidence from Southern Highlands of Ethiopia', in Holden, S. T., Otsuka, K. and Place, F., eds., The Emergence of Land Markets in Africa: Assessing the Impacts on Poverty and Efficiency: RFF Press.

T. Teklu and A. Lemi (2004), 'Factors affecting entry and intensity in informal rental land markets in Southern Ethiopian highlands', Agricultural Economics 30: 117-128.

M. O. Tikabo, S. T. Holden and O. Bergland (2007), 'Factor Market Imperfections and the Land Rental Market in the Highlands of Eritrea: Theory and Evidence.' Revised for Land Economics.

WB (2006), 'Land Policy and Administration', in: The World Bank.

J. Wooldridge (2005), 'Simple Solutions to the Initial Conditions Problem in Dynamic, Nonlinear Panel Data Models with Unobserved Heterogeneity', Journal of Applied Econometrics 20: 39-54. 